\title{
PENGEMBANGAN INSTRUMEN TES UNTUK MENGUKUR KEMAMPUAN KONEKSI MATEMATIS
}

\section{DEVELOPMENT TEST INSTRUMENT FOR MEASURING MATHEMATICAL CONNECTION ABILITY ON MATHEMATICS}

\author{
Andi Dian Angriani ${ }^{1}$, Nursalam ${ }^{2}$, Tenri Batari ${ }^{3}$ \\ ${ }^{1,2,3}$ Fakultas Tarbiyah dan Keguruan UIN Alauddin Makassar \\ ${ }^{1,2,3}$ Kampus II: Jalan H. M. Yasin Limpo Nomor 36 Samata-Gowa \\ E-mail: dian.angriani@uin-alauddin.ac.id ${ }^{1}$, nursalam ftk@uin-alauddin.ac.id ${ }^{2}$, \\ tenribatari07@gmail.com
}

\begin{abstract}
Abstrak
Penelitian ini bertujuan untuk mengetahui prosedur dan menilai kualitas pengembangan instrumen tes untuk mengukur kemampuan koneksi matematis siswa SMP di kota Makassar. Jenis penelitian ini adalah penelitian pengembangan research and development dengan model formative research yang melalui empat tahap, yaitu preliminary, self-evaluation, dan prototyping, serta field. Subjek uji coba pada penelitian ini sebanyak 34 siswa. Hasil yang diperoleh pada uji validitas isi soal dinyatakan valid karena nilai CVR dan CVI yaitu 1 dengan kategori sangat sesuai. Hasil respon siswa memenuhi kriteria tercapai. Reliabilitas instrumen tes dinyatakan reliabel, dimana nilai reliabilitas yaitu 0,75 dengan interpretasi tinggi. Sedangkan dari segi tingkat kesukaran rata-rata skor total yaitu 0,542 dengan kategori sedang. Dari segi daya pembeda rata-rata skor total yaitu 0,45 dengan kategori baik. Selain itu, hasil analisis kemampuan koneksi matematis menggunakan instrumen yang telah dikembangkan diketahui bahwa dari 34 siswa terdapat 3 siswa $(8,82 \%)$ yang termasuk dalam kategori memiki tingkat kemampuan koneksi matematis sangat baik, 17 siswa (50\%) yang termasuk kategori baik, 11 siswa $(32,35 \%)$ termasuk kategori cukup, dan 3 siswa $(8,82 \%)$ termasuk kategori kurang. Rata-rata kemampuan koneksi matematis siswa adalah 52,49 dengan kategori baik karena $51<\bar{x}$ skor total 75 . Dengan demikian, instrumen tes kemampuan koneksi matematis yang dikembangkan memenuhi kualitas yang baik.
\end{abstract}

Kata Kunci: Instrumen Tes, Koneksi Matematis

\begin{abstract}
This study aims to determine the development of procedures and quality of test instruments to measure the ability of mathematical connections of students on mathematics subjects in Makassar city. The type of research is research and development with formative research model through (four) stage that is introduction, self evaluation, and prototype, and field test. The subjects of this study were students of junior high school in Makassar city with the number of students. The results obtained on the validity of the content validity test because CVR and CVI is 1 with very appropriate category. Results of student responses meet the criteria achieved. Reliability, 0.6 with high interpretation. Medium in terms of the average level of difficulty the total score is 0.542 with the medium category. In terms of power differentiate the average total score is 0.45 with good category. In addition, the result of mathematical connection ability analysis using the developed instrument is known that from 34 students there are 3 students $(8.82 \%)$ which included in the category memiki level of excellent mathematical connection ability, 17 students (50\%) including good category, 11 students (32.35\%) included enough category, and 3 students $(8,82 \%)$ including less category. The average mathematical connection ability of students is 52.49 with good category because $51<\bar{x}$ total score 75 . Thus, the test instrument of mathematical connection ability developed to meet the good quality.
\end{abstract}

Keywords: Test Instruments, Mathematical Connection 


\section{Pendahuluan}

Belajar merupakan suatu kegiatan untuk mendapatkan suatu tingkat kepandaian dalam menguasai sebuah ilmu. Dalam memenuhi kebutuhannya untuk mendapatkan tingkatan kepandaian diperlukan usaha yang lebih agar manusia tahu, mengerti, memahami, dan dapat menguasai sesuatu (Kusyairy, 2014: 8). Belajar merupakan kegiatan yang sangat kompleks apabila dikaitkan dengan hasil belajar siswa. Hasil belajar digunakan untuk mengukur penguasaan materi dan mengetahui keberhasilan guru dalam mengajar. Oleh karena itu, guru perlu memperhatikan hasil belajar siswa. Setiap proses dan hasil belajar perlu dievaluasi agar guru dapat menindaklanjuti apa yang harus dilakukan dan metode apa yang seharusnya diberikan, tak terkecuali pada mata pelajaran matematika.

Matematika sangat berperan penting dalam berbagai disiplin ilmu, mendasari perkembangan teknologi serta pengembangan daya pikir manusia yang menjadikannya sebagai ilmu universal (Indah, Mania, \& Nursalam, 2016). Matematika adalah ilmu yang terstruktur dan sistematis sehingga menjadi mata pelajaran dasar pada semua jenjang pendidikan, artinya konsep dan prinsip dalam matematika memiliki kaitan satu sama lain, hal ini sesuai dengan hasil penelitian Zaerani yang menunjukkan penguasaan konsep teorema Phytagoras berpengaruh terhadap kemampuan menyelesaikan soal-soal bangun ruang (Zaerani, Mardhiah, \& Suharti, 2017). Jerome Bruner dalam teorinya menyatakan bahwa cara terbaik bagi siswa mempelajari ide matematika adalah membantu mereka sedemikan sehingga mereka dapat mengaitkan ide yang satu dengan ide lainnya yang relevan (Mustamin, 2013: 187). Memahami konsep matematika dan menjelaskan keterkaitannya merupakan salah satu tujuan pembelajaran matematika menurut BSNP (Musriliani, Marwan, \& Ansari, 2015: 50), sehingga kemampuankemampuan matematis akan dimiliki siswa ketika belajar matematika, salah satunya kemampuan koneksi matematis.

Koneksi matematis memiliki arti yaitu kaitan antar topik dalam matematika, kaitan antara topik dalam matematika dengan bidang lain, dan kaitannya dengan kehidupan sehari-hari (Edy, 2013: 204). Kemampuan membuat koneksi (connection) adalah salah satu kemampuan yang harus dibutuhkan oleh siswa dalam belajar mengaitkan ide-idenya (mathematical connections). Menurut Baki, Çatlioğlu, Coştu, \& Birgin (2009: 1406) jika aktivitas ini dapat dilakukan dalam proses pengajaran, teori dan prakteknya akan saling melengkapi satu sama lain dan objek yang diharapkan dapat dicapai. Hal ini akan membantu siswa melihat hubungan antara kehidupan nyata dengan koneksi matematis di dalam memecahkan permasalahan matematika.

Namun pada kenyataannya, dalam pembelajaran matematika yang dilaksanakan selama ini siswa masih kurang mampu dalam mengaitkan konsep yang dipelajari dengan konsep sebelumnya, menyebabkan rendahnya kemampuan koneksi matematis. Hasil survei Trends International Mathematics and Science Study (TIMSS) dan Programme for International Student Assessment (PISA). Pada PISA tahun 2015 Indonesia hanya menduduki peringkat 69 dari 76 negara. Hasil survei TIMSS juga tidak jauh berbeda dengan hasil survei dari PISA pada tahun 2015 Indonesia menduduki rangking 36 dari 49 negara. Selain itu, Hasil penelitian yang dilakukan oleh (Sugiman, n.d.: 9) pada siswa kelas IX di Yogyakarta menunjukkan bahwa rata-rata kemampuan koneksi matematis siswa tergolong rendah yaitu 53,5\%. Penelitian lain yang dilakukan oleh (Anandita, 2015: 94) menyatakan bahwa dari 37 siswa diperoleh tingkat kemampuan koneksi matematis 18 siswa termasuk dalam kategori "kurang sekali", 10 
siswa termasuk dalam kategori "kurang", 6 siswa dalam kategori "cukup", 2 siswa dalam kategori "baik", dan 1 siswa dalam kategori "baik sekali".

Suatu instrumen berperan penting untuk menjaring hasil pembelajaran (AlTabany, 2014: 218), sedangkan tes merupakan instrumen untuk mengumpulkan data peserta yang memberikan respons terhadap pertanyaan agar peserta dapat menunjukkan kemampuan dan penguasaan maksimum yang dimilliki (Purwanto, 2014: 63-64). Menurut Nursalam (2016: 3) untuk mengetahui tingkat pengetahuan, keterampilan, intelegensi, bakat atau kemampuan seseorang dapat dilakukan tes dengan memberikan sejumlah pertanyaan. Instrumen tes dalam evaluasi pembelajaran merupakan alat ukur yang dapat digunakan untuk menilai atau mengevaluasi sejauh mana proses pembelajaran mencapai sasaran.

Dalam dunia pendidikan pengukuran adalah memberikan tanda atau angka pada sebuah hasil tes atau bentuk lain dari asesmen berdasarkan aturan tertentu (Mania, 2012: 1-2). Dalam menggambarkan karakteristik suatu objek secara sistematis dapat dilakukan dengan memberikan tanda atau angka. Tetapi dalam pelaksanaannya pengukuran harus memiliki kesalahan sekecil mungkin walaupun dalam pengukuran ilmu-ilmu alam pasti memiliki kesalahan. Menurut Mardapi (2008: 2) sebagian besar kesalahan tersebut disebabkan oleh alat ukur, cara ukur serta keadaan objek yang diukur, sedangkan penilaian mengandung arti yang lebih luas dari pengukuran dimana penilaian berfokus untuk menggambarkan hasil belajar peserta didik yang diperoleh dari penerapan informasi-informasi. Penilaian digunakan untuk menjadi dasar dalam mengevaluasi program pembelajaran. Dengan kata lain, penilaian dapat menjadi penunjang agar kompetensi lulusan sesuai dengan yang ditargetkan (Mania, 2014: 25).

Berdasarkan analisis soal yang dilakukan siswa SMP Negeri 17 Makassar, menunjukkan bahwa pada umumnya bentuk soal yang digunakan adalah bentuk pilihan ganda yang disertai dengan penjelasan, yakni soal-soal tersebut langsung menggunakan rumus tanpa adanya proses analisis terlebih dahulu, sehingga soal-soal tersebut kurang cocok untuk mengukur tingkat kemampuan koneksi matematis siswa.

Koneksi matematis merupakan hubungan antara konsep matematika secara internal dan eksternal. Secara internal dapat diartikan sebagai hubungan antar konsep dalam matematika, sedangkan secara eksternal yaitu hubungan antara matematika dengan bidang lain maupun dengan kehidupan sehari-hari. Oleh karena itu, siswa harus banyak diberikan kesempatan untuk melihat keterkaitan-keterkaitan konsep-konsep tersebut agar siswa dapat berhasil dalam belajar matematika. Menurut Abdul, Citra, \& Afidah (2014: 23), indikator dari kemampuan koneksi matematis antara lain: menemukan hubungan berbagai representasi dari konsep, menerapkan matematika di bidang lain, dan menerapkan matematika di kehidupan sehari-hari.

Penelitian terkait pengembangan instrumen tes untuk mengukur kemampuan koneksi matematis juga telah dilakukan oleh Ramdani (2012); Hendriana, Slamet, \& Sumarmo (2014); Nopriyanti (2015); Rohendi \& Dulpaja (2013); Tiara, Epon, \& Oyon (2015); Nursalam, Angriani, A.D., \& Usman H.). Oleh karena itu, peneliti ingin mengembangkan instrumen tes untuk mengukur kemampuan koneksi matematis siswa dengan tujuan agar tes ini dapat mengatasi kesulitan-kesulitan belajar yang dihadapi siswa. Adapun tes yang diujikan kepada siswa berbentuk soal-soal untuk mengukur kemampuan koneksi. Berdasarkan latar belakang di atas, peneliti merasa topik ini perlu untuk diteliti lebih lanjut dalam hal mengembangkan instrumen tes untuk mengukur kemampuan koneksi. 


\section{Metode Penelitian}

Jenis penelitian ini adalah penelitian pengembangan (Research and Development) dengan model tipe formative research yang melalui empat tahap yaitu preliminary, self evaluation (analisis kurikulum, analisis materi, analisis siswa, dan desain), prototyping (validasi, evaluasi, dan revisi) dan field test (uji coba lapangan). Adapun prosedur pengembangan dalam penelitian ini adalah sebagai berikut:

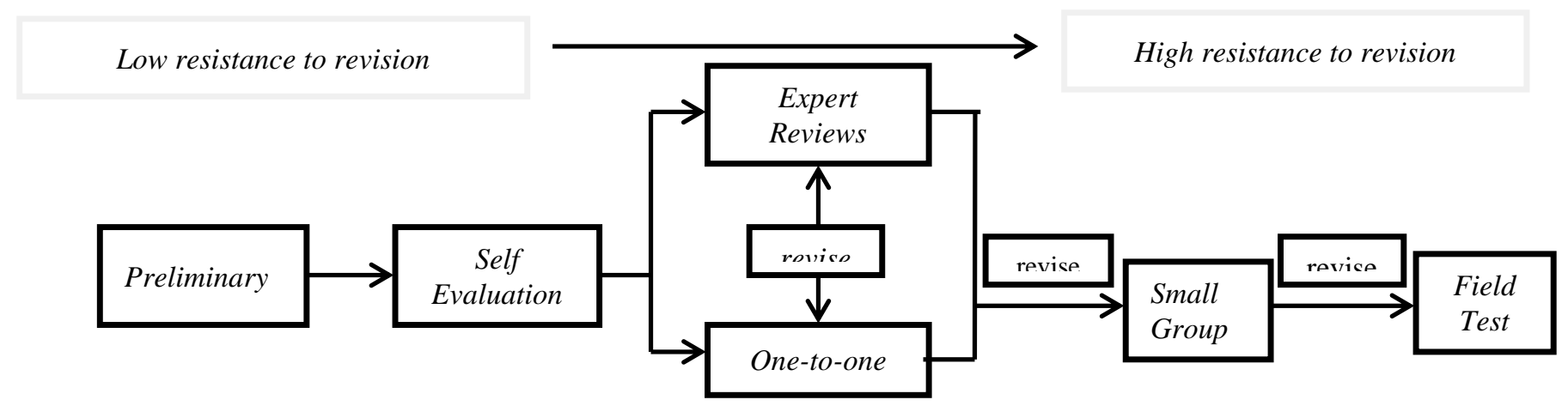

Gambar 1. Alur Pengembangan Model Tessmer

Berdasarkan gambar alur pengembangan Tessmer adapun desain uji coba yang digunakan pada penelitian ini, dapat dilihat pada gambar berikut.

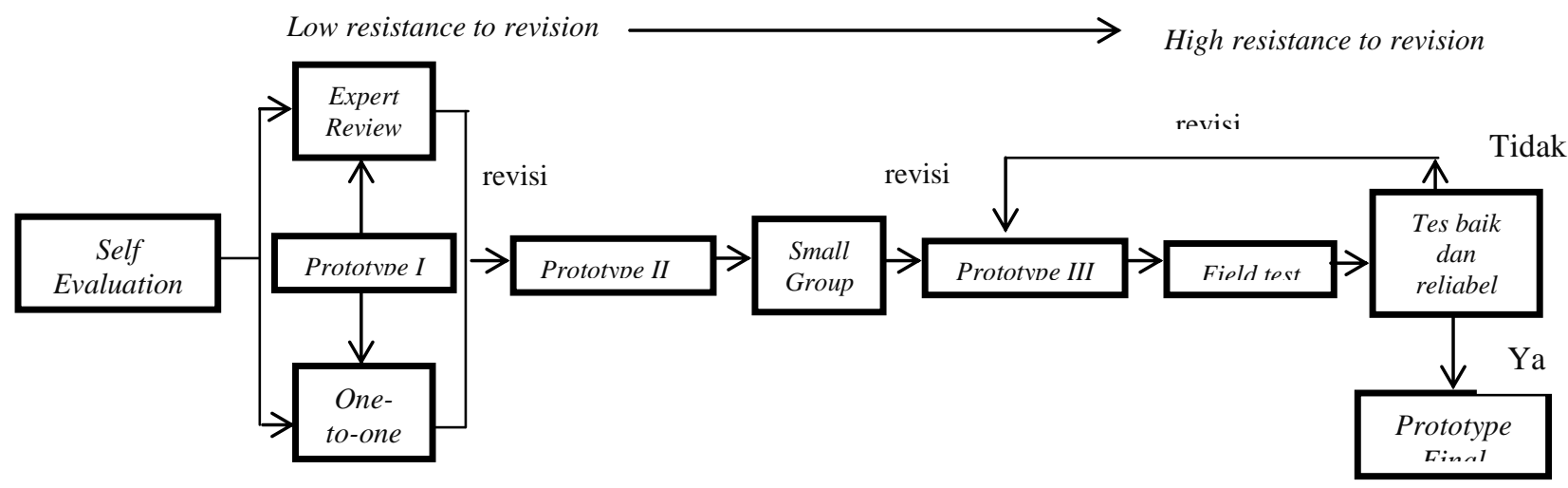

Gambar 2. Desain Uji Coba

Subjek uji coba pada penelitian ini adalah siswa SMP yang berjumlah 34 siswa. Teknik pengumpulan data adalah tes dan angket. Instrumen pengumpulan data adalah instrumen tes, lembar validasi, dan angket. Instrumen tes pada pada penelitian ini menggunakan soal-soal matematika pokok bahasan persamaan linear dua variabel, persamaan kuadrat, lingkaran, bangun ruang sisi datar, perbandingan, dan peluang. Tes yang diujikan dalam bentuk uraian yang disesuaikan dengan indikator kemampuan koneksi matematis. Lembar validasi diarahkan pada validasi konten, konstruk, dan bahasa. Sedangkan angket digunakan untuk mengumpulkan informasi terhadap respon siswa terhadap instrumen tes kemampuan koneksi matematis. Teknik analisis data yang digunakan pada instrumen tes kemampuan koneksi matematis adalah analisis validitas isi soal, analisis angket respon siswa, uji reliabilitas, uji tingkat kesukaran, uji daya pembeda, dan analisis data hasil kemampuan koneksi matematis. 


\section{Hasil dan Pembahasan}

\subsection{Prosedur Pengembangan Instrumen Tes Untuk Mengukur Kemampuan Koneksi Matematis}

Pengembangan instrumen tes untuk mengukur kemampuan koneksi matematis siswa telah melalui serangkaian fase pengembangan tipe formative research mulai dari tahap preliminary, self evaluation, protyping, hingga tahap field test sehingga menghasilkan sebuah produk. Tahap Preliminary merupakan tahap awal atau pendahuluan proses pengembangan. Pada tahap ini peneliti mencari referensi tentang instrumen tes untuk mengukur kemampuan koneksi matematis dan menentukan tempat uji coba penelitian. Tahap selanjutnya adalah tahap self evaluation. Pada tahap ini peneliti melakukan analisis kurikulum, analisis siswa, analisis materi, dan merancang serta mengembangkan instrumen tes untuk mengukur kemampuan koneksi matematis berupa kisi-kisi, soal tes, kunci jawaban, dan pedoman penilaian, serta instrumeninstrumen penelitian lainnya. Kemudian hasil pengembangan instrumen tes koneksi matematis dikonsultasikan dengan dosen pembimbing sehingga menghasilkan Prototype I. Tahap selanjutnya adalah tahap Prototyping yang meliputi penilaian oleh pakar (Expert), One-to-one, dan small group. Instrumen tes yang dikembangkan divalidasi oleh validator. Hasil penilaian dari validator kemudian diuji cobakan kepada tiga siswa (One-to-one). Tujuannya untuk mengetahui keterbacaan soal dan penilaian siswa terhadap instrumen tes koneksi matematis. Hasil penilaian dari validator dan oneto-one selanjutnya digunakan untuk merevisi Prototype I yang akan menghasilkan Prototype II. Kemudian Prototype II diuji cobakan pada 6 siswa (small group). Hasil dari small group selanjutnya digunakan untuk merevisi Prototype II yang akan menghasilkan Prototype III. Prototype III inilah yang akan digunakan pada uji coba lapangan (Field Test). Tahap Field Test yaitu uji coba lapangan dimana instrumen tes yang telah dikembangkan diuji cobakan pada subjek penelitian yaitu kelas IX. 1 SMP Negeri 17 Makassar. Pada tahap ini diperoleh data untuk mengukur reliabilitas, tingkat kesukaran, dan daya pembeda serta mengetahui hasil kemampuan koneksi matematis siswa.

\subsection{Kualitas Instrumen Tes yang Dikembangkan}

\subsubsection{Validitas Isi}

Uji validitas isi yang dilakukan adalah Content Validity Ratio (CVR). Para ahli yang terlibat dalam proses penilaian validitas isi instrumen tes untuk mengukur kemampuan koneksi matematis ini antara lain: dua orang dosen program studi pendidikan matematika, dan satu orang guru mata pelajaran matematika. Hasil validitas isi dengan menggunakan CVR dapat dilihat pada tabel berikut:

Tabel 1. Hasil validitas isi I dengan CVR

\begin{tabular}{ccccccc}
\hline Butir & Expert & Expert & Expert & \multirow{2}{*}{ CVR } & CVI & Keterangan \\
Soal & 1 & 2 & 3 & & & \\
\hline 1 & 1 & 0 & 1 & 0.33 & 0.8213 & Butir tidak mendukung validitas isi tes \\
\hline 2 & 1 & 1 & 1 & 1 & & Butir tidak mendukung validitas isi tes \\
\hline 3 & 1 & 0 & 1 & 0.33 & & Butir tidak mendukung validitas isi tes \\
\hline 4 & 1 & 1 & 1 & 1 & & Butir mendukung validitas isi tes \\
\hline
\end{tabular}




\begin{tabular}{cccccc}
\hline 5 & 1 & 1 & 1 & 1 & Butir mendukung validitas isi tes \\
\hline 6 & 1 & 0 & 1 & 0.33 & Butir tidak mendukung validitas isi tes \\
\hline 7 & 1 & 1 & 1 & 1 & Butir mendukung validitas isi tes \\
\hline 8 & 1 & 1 & 1 & 1 & Butir mendukung validitas isi tes \\
\hline 9 & 1 & 1 & 1 & 1 & Butir mendukung validitas isi tes \\
\hline 10 & 1 & 1 & 1 & 1 & Butir mendukung validitas isi tes \\
\hline 11 & 1 & 0 & 1 & 0.33 & Butir mendukung validitas isi tes \\
\hline 12 & 1 & 1 & 1 & 1 & Butir mendukung validitas isi tes \\
\hline 13 & 1 & 1 & 1 & 1 & Butir mendukung validitas isi tes \\
\hline 14 & 1 & 1 & 1 & 1 & Butir mendukung validitas isi tes \\
\hline 15 & 1 & 1 & 1 & 1 & \\
\hline Total & & & & 12,32 & \\
\hline
\end{tabular}

Berdasarkan tabel 1 dapat diketahui bahwa terdapat 4 butir soal yang harus direvisi dikarenakan nilai CVR yang dihasilkan $\leq 0,99$. Butir soal tersebut adalah butir soal nomor 1, 3, 6, dan 11. Revisi ini dilakukan dengan adanya masukan dari validator kemudian dilakukan validasi isi kembali untuk memperoleh instrumen tes yang layak digunakan. Hasil perhitungan validasi isi yang kedua menggunakan CVR dapat dilihat pada tabel 2 berikut:

Tabel 2. Hasil Validasi Isi 2 dengan CVR

\begin{tabular}{|c|c|c|c|c|c|c|}
\hline $\begin{array}{l}\text { Butir } \\
\text { Soal }\end{array}$ & $\begin{array}{c}\text { Expert } \\
1\end{array}$ & $\begin{array}{c}\text { Expert } \\
2\end{array}$ & $\begin{array}{c}\text { Expert } \\
3\end{array}$ & CVR & CVI & Keterangan \\
\hline 1 & 1 & 1 & 1 & 1 & 1 & Butir mendukung validitas isi tes \\
\hline 2 & 1 & 1 & 1 & 1 & & Butir mendukung validitas isi tes \\
\hline 3 & 1 & 1 & 1 & 1 & & Butir mendukung validitas isi tes \\
\hline 4 & 1 & 1 & 1 & 1 & & Butir mendukung validitas isi tes \\
\hline 5 & 1 & 1 & 1 & 1 & & Butir mendukung validitas isi tes \\
\hline 6 & 1 & 1 & 1 & 1 & & Butir mendukung validitas isi tes \\
\hline 7 & 1 & 1 & 1 & 1 & & Butir mendukung validitas isi tes \\
\hline 8 & 1 & 1 & 1 & 1 & & Butir mendukung validitas isi tes \\
\hline 9 & 1 & 1 & 1 & 1 & & Butir mendukung validitas isi tes \\
\hline 10 & 1 & 1 & 1 & 1 & & Butir mendukung validitas isi tes \\
\hline 11 & 1 & 1 & 1 & 1 & & Butir mendukung validitas isi tes \\
\hline 12 & 1 & 1 & 1 & 1 & & Butir mendukung validitas isi tes \\
\hline 13 & 1 & 1 & 1 & 1 & & Butir mendukung validitas isi tes \\
\hline 14 & 1 & 1 & 1 & 1 & & Butir mendukung validitas isi tes \\
\hline 15 & 1 & 1 & 1 & 1 & & Butir mendukung validitas isi tes \\
\hline Jumlah & & & & 15 & & \\
\hline
\end{tabular}

Berdasarkan tabel 2 menunjukkan bahwa hasil validasi isi soal telah memenuhi kriteria validitas isi tes dimana nilai CVR adalah 1 . Kemudian nilai CVR tersebut digunakan untuk menentukan nilai CVI (Content Validity Index) yang merupakan rata- 
rata dari CVR. Nilai CVI semua item yang diperoleh sebesar 1. Artinya, semua butir soal sangat sesuai dalam mengukur kemampuan koneksi matematis.

\subsubsection{Uji Angket Respon Siswa}

Tabel 3. Hasil Angket Respon Siswa

\begin{tabular}{ccc}
\hline Uji Coba & Respon Positif & Respon Negatif \\
\hline One-to-one & $75 \%$ & $25 \%$ \\
\hline Small Group & $62,5 \%$ & $37,5 \%$ \\
\hline Rata-rata respon siswa & $68,5 \%$ & $31,25 \%$ \\
\hline
\end{tabular}

Berdasarkan tabel 3 angket respon siswa di atas menunjukkan bahwa pada uji coba one-to-one diperoleh rata-rata respon positif siswa adalah $75 \%$ dan rata-rata respon negatif siswa adalah $25 \%$. Sedangkan pada uji coba small group rata-rata respon positif siswa adalah $62,5 \%$ dan rata-rata respon negatif siswa adalah $37,5 \%$. Sehingga rata-rata respon positif siswa adalah $68,5 \%$. Sedangkan rata-rata respon negatif angket respon siswa adalah $31,25 \%$. Sehingga angket respon siswa memenuhi kriteria "tercapai" dan tidak ada perbaikan/revisi terhadap instrumen tes yang dikembangkan karena lebih dari $50 \%$ siswa yang memberikan respon positif.

\subsubsection{Uji Reliabilitas}

Uji reliabilitas ini berdasarkan hasil uji coba lapangan (field test) yang melibatkan siswa kelas IX.1 SMP Negeri 17 Makassar. Banyak siswa di kelas IX.1 adalah 34 siswa. Siswa diminta menyelesaikan 15 soal uraian dengan waktu $2 \times 40$ menit. Berikut perhitungan uji reliabilitas tes ditunjukkan pada tabel 4.

Tabel 4. Data Reliabilitas Instrumen Tes Reliability Statistics

Cronbach's Alpha N of Items

.746

Berdasarkan hasil analisis reliabilitas instrumen tes kemampuan koneksi menggunakan SPSS versi 20 diketahui bahwa instrumen tes untuk mengukur kemampuan koneksi matematis siswa tergolong reliabel dengan nilai sebesar 0.746 dengan interpretasi tinggi. Hal ini berarti, instrumen tes untuk mengukur kemampuan koneksi matematis tergolong reliabel. Artinya instrumen tes yang telah dikembangkan dapat dipercaya dan memberikan hasil yang sama apabila tes ini dilakukan pada subyek, tempat maupun kondisi yang berbeda.

\subsubsection{Tingkat Kesukaran}

Butir-butir instrumen tes dapat dikatakan baik apabila butir-butir tes tersebut memiliki tingkat kesukaran pada interval 0,31-0,70. Hal ini menunjukkan bahwa butir tersebut soal tidak terlalu sulit dan juga tidak terlalu mudah. Tingkat kesukaran 
instrumen yang dikembangkan juga diperoleh dari data hasil pekerjaan siswa pada uji coba lapangan (field test). Analisis tingkat kesukaran tiap-tiap item soal ditunjukkan pada tabel 5 berikut:

Tabel 5. Hasil Analisis Tingkat Kesukaran Instrumen Tes

\begin{tabular}{ccc}
\hline No. Soal & Tingkat Kesukaran & Kategori \\
\hline 1 & 0,84 & Mudah \\
\hline 2 & 0,79 & Mudah \\
\hline 3 & 0,33 & Sedang \\
\hline 4 & 0,56 & Sedang \\
\hline 5 & 0,63 & Sedang \\
\hline 6 & 0,37 & Sedang \\
\hline 7 & 0,62 & Sedang \\
\hline 8 & 0,52 & Sedang \\
\hline 9 & 0,72 & Mudah \\
\hline 10 & 0,71 & Mudah \\
\hline 11 & 0,39 & Sedang \\
\hline 12 & 0,56 & Sedang \\
\hline 13 & 0,37 & Sedang \\
\hline 14 & 0,27 & Sukar \\
\hline 15 & 0,45 & Sedang \\
\hline Rata-Rata & 0,542 & Sedang \\
\hline
\end{tabular}

Berdasarkan hasil analisis butir soal dari segi tingkat kesukaran instrumen tes kemampuan koneksi matematis diketahui bahwa dari 15 soal yang diuji cobakan terdapat 4 soal kategori mudah, 10 soal kategori sedang, dan 1 soal kategori sukar. Hasil rata-rata tingkat kesukaran yaitu 0,542 dengan kategori sedang. Dengan demikian, kualitas instrumen tes untuk mengukur kemampuan koneksi yang telah dikembangkan dari segi tingkat kesukaran memiliki kualitas yang baik.

\subsubsection{Daya Pembeda}

Butir-butir instrumen tes dapat dikatakan baik apabila butir-butir tes tersebut memiliki daya beda paling kecil adalah 0,2. Hal ini menunjukkan bahwa butir-butir soal memiliki daya beda minimal cukup. Daya pembeda item instrumen tes yang dikembangkan diperoleh dari data hasil pekerjaan siswa pada uji coba lapangan (field test). Hasil analisis daya beda instrumen tes ditunjukkan pada tabel 6 . 
Tabel 6. Hasil Analisis Daya Pembeda Instrumen Tes

\begin{tabular}{ccc}
\hline No. Soal & Daya Beda & Kategori \\
\hline 1 & 0,22 & Cukup \\
\hline 2 & 0,16 & Jelek \\
\hline 3 & 0,32 & Cukup \\
\hline 4 & 0,33 & Cukup \\
\hline 5 & 0,14 & Jelek \\
\hline 6 & 0,37 & Cukup \\
\hline 7 & 0,60 & Baik \\
\hline 8 & 0,70 & Baik \\
\hline 9 & 0,22 & Cukup \\
\hline 10 & 0,44 & Baik \\
\hline 11 & 0,49 & Baik \\
\hline 12 & 0,78 & Sangat Baik \\
\hline 13 & 0,86 & Sangat Baik \\
\hline 14 & 0,53 & Baik \\
\hline 15 & 0,67 & Baik \\
\hline Rata-rata & 0,45 & Baik \\
\hline & &
\end{tabular}

Berdasarkan hasil analisis butir soal dari segi daya pembeda diketahui bahwa kesukaran instrumen tes kemampuan koneksi matematis diketahui bahwa dari 15 soal yang diuji cobakan terdapat 2 butir soal dengan kategori jelek, 5 butir soal dengan kategori cukup, 6 butir soal dengan kategori baik, dan 2 butir soal dengan kategori sangat baik. Sehingga diperoleh rata-rata daya pembeda yaitu 0,45 dengan kategori baik.

Berdasarkan penjelasan di atas, ternyata ada beberapa butir soal yang menurut para ahli telah mendukung validitas isi, namun berdasarkan hasil uji coba lapangan butir-butir tersebut tidak memenuhi kualitas instrumen tes yang baik yang telah ditetapkan. Seperti pada butir 1, 2, 9, dan 10 serta 14 menurut para ahli mendukung validitas isi, namun berdasarkan hasil uji coba lapangan tidak memenuhi kriteria instrumen yang baik dari segi tingkat kesukaran. Selain itu, pada soal butir 2, dan 5 menurut para ahli butir tersebut mendukung validitas isi, namun berdasarkan hasil uji coba lapangan tidak memenuhi kriteria daya pembeda yang baik.

\subsection{Hasil Analisis Kemampuan Koneksi Matematis Siswa}

Mengukur hasil tes kemampuan koneksi matematis siswa dapat diperoleh dari skor akhir yang diperoleh setelah soal tes kemampuan koneksi matematis dikerjakan. Penentuan tingkat kemampuan koneksi matematis siswa dapat dilakukan dengan menganalisis dan mengonversikan data yang telah diperoleh ke dalam bentuk data kualitatif. Hasil analisis hasil tes kemampuan koneksi matematis siswa ditunjukkan pada tabel 7 berikut: 
Tabel 7. Analisis Hasil Tes Kemampuan Koneksi Matematis Siswa

\begin{tabular}{ccccc}
\hline No. & Nilai siswa & Frekuensi & Persentase $(\%)$ & Kategori \\
\hline 1 & $76 \leq$ nilai $\leq 100$ & 3 & 8.82 & Sangat baik \\
\hline 2 & $51 \leq$ nilai $\leq 75$ & 17 & 50.00 & Baik \\
\hline 3 & $26 \leq$ nilai $\leq 50$ & 11 & 32.35 & Cukup \\
\hline 4 & $0<$ nilai $\leq 25$ & 3 & 8.82 & Kurang \\
\hline & Jumlah Subyek & 34 & 100.00 & Baik \\
\hline & Rata-rata & 52.49 & & \\
\hline
\end{tabular}

Berdasarkan hasil uji coba lapangan (Field Test), selain diperoleh kualitas instrumen tes yang dikembangkan juga diperoleh hasil kemampuan koneksi matematis siswa. Analisis ini bertujuan untuk mengetahui nilai kemampuan koneksi siswa dalam kategori sangat baik, baik, cukup dan kurang.. Berdasarkan hasil analisis diperoleh ratarata kemampuan koneksi matematis siswa yaitu 52,49 dengan kategori cukup sehingga masih sangat dibutuhkan usaha lebih lanjut oleh guru agar dapat memberikan soal-soal yang dapat memacu kemampuan koneksi matematis. Adapun jumlah siswa dengan kemampuan koneksi sangat baik yaitu 3 siswa (8,82\%), 17 siswa (50\%) yang termasuk dalam kategori memiki tingkat kemampuan koneksi matematis baik, 11 siswa $(32,35 \%)$ yang termasuk dalam kategori memiliki tingkat kemampuan koneksi matematis cukup, dan 3 siswa $(8,82 \%)$ yang termasuk dalam kategori memiliki tingkat kemampuan koneksi matematis kurang.

\section{Kesimpulan}

Proses pengembangan instrumen tes untuk mengukur kemampuan koneksi matematis matematika siswa melalui empat tahap, yaitu tahap preliminary, tahap selfevaluation, tahap prototyping, dan tahap field test. Hasil yang diperoleh pada uji validitas isi soal dinyatakan valid karena nilai CVR dan CVI yaitu 1 dengan kategori sangat sesuai. Hasil respon siswa memenuhi kriteria tercapai. Reliabilitas instrumen tes dinyatakan reliabel, dimana nilai reliabilitas yaitu 0,75 dengan interpretasi tinggi. Sedangkan dari segi tingkat kesukaran rata-rata skor total yaitu 0,542 dengan kategori sedang. Dari segi daya pembeda rata-rata skor total yaitu 0,45 dengan kategori baik. Selain itu, hasil analisis kemampuan koneksi matematis menggunakan instrumen yang telah dikembangkan diketahui bahwa dari 34 siswa terdapat 3 siswa $(8,82 \%)$ yang termasuk dalam kategori memiki tingkat kemampuan koneksi matematis sangat baik, 17 siswa $(50 \%)$ yang termasuk kategori baik, 11 siswa $(32,35 \%)$ termasuk kategori cukup, dan 3 siswa $(8,82 \%)$ termasuk kategori kurang. Rata-rata kemampuan koneksi matematis siswa adalah 52,49 dengan kategori baik karena $51<\bar{x}$ skor total 75 . Dengan demikian, instrumen tes kemampuan koneksi matematis yang dikembangkan memenuhi kualitas yang baik. 


\section{Daftar Pustaka}

Abdul, M., Citra, P., \& Afidah, A. (2014). The Achievement of Mathematical Connection Skills Based on Cognitive Level Through Means Ends Analysis (MEA) Strategy Of Learning. In Proceeding of International Conference On Research, Implementation And Education Of Mathematics And Sciences 2014. Yogyakarta State University.

Al-Tabany, T. I. B. (2014). Mendesain Model Pembelajaran Inovatif, Progresif, Dan Kontekstual. Jakarta: Prenadamedia Group.

Anandita, G. P. (2015). Analisis Kemampuan Koneksi Matematis Siswa SMP Kelas VIII Pada Materi Kubus dan Balok. Universitas Negeri Semarang.

Baki, A., Çatlığlu, H., Coştu, S., \& Birgin, O. (2009). Conceptions of high school students about mathematical connections to the real-life. Procedia-Social and Behavioral Sciences, 1(1), 1402-1407. https://doi.org/10.1016/j.sbspro.2009.01.247

EDY, T. (2013). Pengembangan Kemampuan Koneksi Matematissiswa melalui Pendekatan Advokasi dengan Penyajian Masalah Open-Ended pada Pembelajaran Matematika. In Prosiding Seminar Nasional Matematika dan Pendidikan Matematika. Jurusan Pendidikan Matematika FMIPA UNY.

Hendriana, H., Slamet, U. R., \& Sumarmo, U. (2014). Mathematical Connection Ability and Self-Confidence (An experiment on Junior High School students through Contextual Teaching and learning with Mathematical Manipulative). International Journal of Education, 8(1), 1-11.

Indah, N., Mania, S., \& Nursalam, N. (2016). Peningkatan Kemampuan Literasi Matematika Siswa melalui Penerapan Model Pembelajaran Problem Based Learning Di Kelas VII SMP Negeri 5 Pallangga Kabupaten Gowa. MaPan: Jurnal Matematika Dan Pembelajaran, 4(2), 200-210. https://doi.org/https://doi.org/10.24252/mapan.2016v4n2a4

Kusyairy, U. (2014). Psikologi Belajar. Makassar: Alauddin University Press.

Mania, S. (2012). Pengantar Evaluasi Pengajaran. Makassar: Alauddin University Press.

Mania, S. (2014). Asesmen Autentik untuk Pembelajaran Aktif dan Kreatif Implementasi Kurikulum 2013. Makassar: Makassar: Alauddin University Press.

Mardapi, D. (2008). Teknik Penyusunan Instrumen Tes dan Non tes. Yogyakarta: Mitra Cendekia.

Musriliani, C., Marwan, M., \& Ansari, B. I. (2015). Pengaruh Pembelajaran Contextual Teaching Learning (CTL) terhadap Kemampuan Koneksi Matematis Siswa SMP Ditinjau dari Gender. Jurnal Didaktik Matematika, 2(2). 
Mustamin, S. H. (2013). Psikologi Pembelajaran Matematika. Makassar: Alauddin University Press.

Nopriyanti, T. D. (2015). Pengembangan Soal Matematika Untuk Mengukur Kemampuan Koneksi Matematis Siswa. Jurnal Dosen Universitas PGRI Palembang.

Nursalam, N. (2016). Diagnostik Kesulitan Belajar Matematika: Studi pada Siswa SD/MI di Kota Makassar. Lentera Pendidikan, 19(1), 1-15.

Purwanto. (2014). Evaluasi Hasil Belajar (VI). Pustaka Pelajar.

Ramdani, Y. (2012). Pengembangan Instrumen dan Bahan Ajar Untuk Meningkatkan Kemampuan Komunikasi, Penalaran, dan Koneksi Matematis Dalam Konsep Integral. Jurnal Penelitian Pendidikan, 13(1), 44-52.

Rohendi, D., \& Dulpaja, J. (2013). Connected Mathematics Project (CMP) Model Based on Presentation Media to the Mathematical Connection Ability of Junior High School Student. Journal of Education and Practice, 4(4), 17-22.

Sugiman, S. (n.d.). Koneksi Matematik dalam Pembelajaran Matematika di Sekolah Menengah Pertama. PYTHAGORAS: Jurnal Pendidikan Matematika, 4(1).

Tiara, P. Y., Epon, N., \& Oyon, H. P. (2015). The Enhancement Ability of Mathematical Connection in Paralellogram Material Through Learning Based on Van Hiele Theory in Class V SDN 1 Cibatuireng. In Proceeding of International Conference On Research, Implementation And Education Of Mathematics And Sciences 2015 (ICRIEMS 2015), Yogyakarta State University, 17-19 May 2015. Faculty of Mathematics and Sciences Yogyakarta State University.

Zaerani, S., Mardhiah, \& Suharti. (2017). Pengaruh Penguasaan Konsep Teorema Pythagoras terhadap Kemampuan Menyelesaikan Soal-Soal Bangun Ruang Sisi Datar pada Siswa Kelas VIII MTs Negeri Balang-Balang. Mapan: Jurnal Matematika Dan Pembelajaran, 5(2), 279-292. https://doi.org/10.24252/mapan.v5n2a9 